\title{
CHOICE AND FEDERAL INTERVENTION IN CORPORATE LAW
}

\author{
Stephen J. Choi* \& Andrew T. Guzman ${ }^{* *}$
}

\section{INTRODUCTION}

CORPORATIONS within the United States have long enjoyed the right to choose the corporate law regime that governs their internal affairs. ${ }^{3}$ A corporation based in Texas may select the corporate law of Texas, or the same corporation may instead select the corporate law of Delaware. Many corporations, regardless of where they operate, choose Delaware corporate law. ${ }^{2}$ The choice available to corporations has generated competition among states for incorporations. Froin this competition has emerged one of the fiercest debates within the corporate law literature: does state competition for incorporations result in a beneficial race-to-the-top or a harmful race-to-the-bottom?

The race-to-the-top argument is straightforward. ${ }^{3}$ Where a corporation selects corporate law rules tliat maximize the interests of

- Visiting Professor, Yale Law School. Professor, Boalt Hall School of Law, University of California at Berkeley.

- Acting Professor, Boalt Hall School of Law, University of California at Berkeley. We are grateful to Lucian Bebchuk, Robert Daines, Allen Ferrell, and Jesse Fried for helpful comments and suggestions. Andrew Guzman thanks the John M. Ohin foundation for financial support. Special thanks to Jeannie Sears, Nicholas James, Un Kyung Park, Alexander Sehan, and Una Emma.

' For a description of the corporate law internal affairs doctrine, see Richard $\mathrm{M}$. Buxbaum. The Threatened Constitutionalization of the Internal Affairs Doctrine in Corporation Law, 75 Cal. L. Rev. 29 (1987).

2 The state of Delaware reports that over 324,000 coinpamies are incorporated in Delaware representing " 60 percent of the Fortune 500 and 50 percent of the companies listed on the New York Stock Exchange." Delaware Division of Corporations, at http://www.state.de.us/corp/mdex.htnı (last modified Apr. 10, 2001).

'For a discussion of the race-to-the-top argument see Frank H. Easterbrook \& Daniel R. Fischel, The Economic Structure of Corporate Law 212-27 (1991); Roberta Romano, Genius of American Corporate Law 2-12 (1993) [hereinafter Romano, Genius of Anierican Corporate Law]; Daniel R. Fischel, The "Race to the Bottonı" Revisited: Reflections on Recent Developinents in Delaware's Corporation Law, 76 Nw. U. L. Rev. 913, 919-20 (1982); Ralph K. Winter, Jr., State Law, Shareholder Protection, and the Theory of the Corporation, 6 J. Legal Stud. 251, 258 (1977).

In the context of securities regulation, several commentators have argued for greater regulatory competition. See Stephen J. Choi \& Andrew T. Guzman, Portable 
shareholders, investors conteinplating the purchase of shares are willing to pay noore for those securities. At the time of the initial incorporation, therefore, corporations have strong incentives to choose corporate law rules that nuaximize shareholder welfare. ${ }^{4}$ Corporations that fail to do so will raise less noney from investors. Because corporations have an incentive to choose optimal rules, states have an incentive to provide such rules as they atteinpt to attract incorporations. ${ }^{5}$

On the other side of the debate, several proininent acadeinics have argued that state conipetition in corporate law generates rules that harm shareholder welfare. ${ }^{6}$ Managers of publicly held corporations, for example, inay cause the corporations to reincorporate in states with more lenient rules regarding nıanagerial self-dealing. ${ }^{7}$ To the extent that shareholders are dispersed and face a collective action problem in voting, shareholders may fail to resist such a "midstream" shift in the corporate law regime. ${ }^{8}$ Under this view of

Reciprocity: Rethinking the International Reach of Securities Regulation, 71 S. Cal. L. Rev. 903 (1998); Alan R. Palmiter, Toward Disclosure Choice in Securities Offerings, 1999 Colum. Bus. L. Rev. 1; Roberta Romano, Empowering Investors: A Market Approach to Securities Regulation, 107 Yale L.J. 2359 (1998). But see Merritt B. Fox, Securities Disclosure in a Globalizing Market: Who Should Regulate Whom, 95 Mich. L. Rev. 2498, 2501-06 (1997) (arguing agamst regulatory choice and advocating instead that the home country of an issuer should regulate the disclosure regime for the issuer regardless of where investors are located or transactions take place).

${ }^{4}$ Michael C. Jensen \& William H. Meckhing, Theory of the Firm: Managerial Behavior, Agency Costs and Ownership Structure, 3 J. Fin. Econ. 305, 305-07 (1976).

s States benefit from incorporations through greater franchise taxes and fees. See Curtis Alva, Delaware and the Market for Corporate Charters: History and Agency, 15 Del. J. Corp. L. 885, 887-88 (1990). In-state law finns and corporate service businesses also benefit from the business derived from increased numbers of incorporations. See William L. Cary, Federalism and Corporate Law: Reflections Upon Delaware, 83 Yale L.J. 663, 668 (1974).

${ }^{6}$ For a discussion of the race-to-the-bottoin hypothesis, see Lucian Arye Bebchuk, Federalism and the Corporation: The Desirable Limits on State Competition in Corporate Law, 105 Harv. L. Rev. 1435, 1455-56 (1992); see also Cary, supra note 5, at 705 (contending that state corporate law coinpetition results in a race to the bottom).

${ }^{7}$ Managers holding ouly a fraction of a firm's equity may, for example, seek to divert value from shareholders toward their own private use. See, e.g., Eugene F. Fama, Agency Problems and the Theory of the Firm, 88 J. Pol. Econ. 288, 288-89 (1980); Eugene F. Fama \& Michael C. Jensen, Separation of Ownership and Control, 26 J.L. \& Econ. 301, 301-04 (1983).

${ }^{8}$ Lucian Arye Bebchuk, Limiting Contractual Freedom in Corporate Law: The Desirable Constraints on Charter Amendments, 102 Harv. L. Rev. 1820, 1827-30 
regulatory competition in corporate law, states compete to provide legal rules that are attractive to managers rather than shareholders, generating a race-to-the-bottoin.

In their essay, A New Approach to Takeover Law and Regulatory Competition, Professors Lucian Bebchuk and Allen Ferrell offer an innovative proposal that seeks to move the debate on regulatory competition forward. ${ }^{9}$ Rather than expand upon wellestablished arguments about the competition for corporate charters, Bebchuk and Ferrell present a regulatory proposal intended to address concerns on both sides of the debate. The goal of their proposal is to adjust the competitive process inherent in the existing regime to align the process of competition more closely with shareholder interests. Focusing solely on the takeover-related portion of corporate law, Bebchuk and Ferrell contend first that shareholders should have an additional choice of law beyond the present selection of fifty different state corporate law regimes governing takeovers. They argue that the federal government should offer a fifty-first regime, asserting that federal rules may provide a more shareholder-oriented alternative. ${ }^{10}$ Second, they propose a procedural rule by which a inajority of shareholders, acting independently of the board of directors, inay unilaterally opt into the federal takeover regime. ${ }^{11}$ Such a reform would remove the management's veto power-held through their control over the board of directors-over reincorporation into a more shareholderfriendly regime. ${ }^{12}$

This Essay assesses the Bebchuk and Ferrell "choice-enhancing federal intervention" proposal. We first applaud Bebchuk and Ferrell's move toward greater choice rather than mandatory fed-

(1989); Jeffrey N. Gordon, The Mandatory Structure of Corporate Law, 89 Colum. L. Rev. 1549, 1573-77 (1989).

'See Lucian Arye Bebchuk \& Allen Ferrell, A New Approach to Takeover Law and Regulatory Competition, 87 Va. L. Rev. 111 (2001).

10 Id. at 143.

"Under their proposal, shareholders are similarly able to opt out of the federal regime. See id. at 147.

12 ld. at 147-48. Delaware law, for example, currently requires that both shareholders and the board of directors approve reincorporation in another state. See Robert C. Clark, Corporate Law $\$ 10.2 .4$, at 416-17 (1986). Charter amendments require both board of director and shareholder inajority approval. See, e.g., Del. Code Ann. tit. 8, \$242(b)(1) (1991); N.Y. Bus. Corp. Law \$ 803(a) (McKinney 1986); Model Bus. Corp. Act $\S 10.03$ (b) (1999). 
eral rules. The federal government, by offering its own takeoverrelated law, may indeed provide needed competition for Delaware corporate law. So long as the federal government does not make its own rules mandatory, the mcreased choice generated by their proposal is desirable.

Though we support Bebchuk and Ferrell's move toward choice, we remain skeptical of the benefits promised by the procedural rule. Were the rule truly mandatory, we would oppose it as potentially harmful. Because the rule is, in fact, a default rule that corporations can opt out of in their charter, ${ }^{13}$ we agree that it is unlikely to cause harm, at least to new corporations, but also suggest that it may provide few benefits. With respect to existing corporations, the proposal would represent a mid-stream shift toward greater shareholder power. Whether such a shift is desirable is an open question. There are reasons why corporations seeking to maximize share value may prefer not to give dispersed public shareholders the power to change the corporate law regime. Block shareholders, for example, may use the threat of a value-decreasing remcorporation to extract money from a corporation. And where a shareholder-only choice rule is desirable, corporations will have strong imcentives to voluntarily opt mto such a regime at the time of their initial incorporation. ${ }^{14}$

${ }^{13}$ Bebchuk \& Ferrell, supra note 9, at 148. A default rule, nevertheless, may matter. A default, for example, may become the legal norm and develop legal certainty around its application. Contracting parties may therefore hesistate to deviate from a default even where they would have preferred a different arrangement if writing from a clean slate. See Michael Klausner, Corporations, Corporate Law, and Networks of Contracts, 81 Va. L. Rev. 757, 772-815 (1995). Given the novelty of Bebchuk and Ferrell's mandatory process rule, a more risk averse approach may therefore seek to enable corporations to opt into the Bebchuk and Ferrell regime rather than make the mandatory process rule the default. See infra note 14.

${ }^{14}$ Soine uncertainty, nevertheless, may exist in the ability of a corporation to adopt a shareholder-only choice rule in the corporate charter. Delaware's General Corporation Law on its face provides that the certificate of incorporation may vary the allocation of power between the board of directors and shareholders. See Del. Code Ann. tit. 8, \& 141(a) (Supp. 2000) ("The business and affairs of every corporation organized under this chapter shall be managed by or under the direction of a board of directors, except as may be otherwise provided in this chapter or in its certificate of incorporation."). To the authors' knowledge, however, no corporation has granted the power to reincorporate the corporation into a new corporate law regime to shareholders only. See also Gordon, supra note 8, at 1592 (calling the allocation of power between directors and shareholders one of the "mandatory rules of corporate law"). Federal regulators interested in implementing a shareholder 
Bebchuk and Ferrell choose not to commit on the question of whether a mandatory regime is better than their choice proposal. ${ }^{15}$ In our view, the arguments against a inandatory federal regime remain strong. In the absence of choice, regulators may succumb to pressure froin well-organized inanagement lobbies, resulting in even more pro-inanagement regimes. Furthermore, monopolistic federal regulators may generate less than optimal regimes in the absence of inarket disciplime. Monopolistic regulators may also adjust their regulatory regime more slowly to changes in the corporate business context than would a inarket driven system. Given the downsides of a mandatory regime, we much prefer Bebchuk and Ferrell's choice-enhancing approach. We seek nonetheless to improve on the choice provided through the Bebchuk and Ferrell proposal.

This Essay will proceed as follows. In Part I we will praise the choice-enhancing elements of Bebchuk and Ferrell's proposal and propose to expand upon their addition of a federal corporate law regime. In Part II we will assess the mandatory shareholder-only reincorporation choice rule proposal.

\section{The Move To CHoICE}

Bebchuk and Ferrell's proposal is separable into two distinct components. First, they argue for the development of a federal law of takeovers. Second, they provide a procedural rule permitting unilateral action on the part of a majority of shareholders to reincorporate into the federal takeover regime. This Part focuses solely on the implications of their proposal for a federal takeover law option. The mandatory shareholder choice rule is discussed in Part II.

Bebchuk and Ferrell claim that their federal takeover law option proposal "dominates" the present "nonintervention[ist]" federal regime, ${ }^{16}$ and that "[c]hoice-enhancing [federal] intervention cannot harm-and would likely improve-the regulation of takeovers." ${ }^{17}$

process rule may wish to do so in a less dramatic fashion, therefore, through the adoption of an enabling rule, providing corporations a clear and certain method of opting into the process rule.

"Bebchuk \& Ferrell, supra note 9, at 160 ("The pohicy choice should be between choice-enhancing intervention and mandatory federal regulation.").

${ }^{16}$ Id. at 115 .

"Id. at 113. 
Under even the most skeptical reading of the Bebchuk and Ferrell argument, their proposal at least generates a fifty-first takeover law option for corporations. The Bebchuk and Ferrell argument that their proposal is preferable to the present fifty option system then rests on a simple premise: more choice cannot be worse than less choice. Adding a fifty-first choice to the existing system of fifty choices-especially a federal choice that Bebchuk and Ferrell argue possesses structural features that favor shareholder welfare enhancing takeover rules-can only expand the range of options available to companies. ${ }^{18}$

The inore-choice-is-better premise is taken directly from the playbook of race-to-the-top theorists. The central argument of race-to-the-bottom proponents has always been that choice in the corporate law context results in a reduction of shareholder wealth to the benefit of opportumistic managers. Prior to Bebchuk and Ferrell's proposal, additional choice was not seen as an improvement by those who argued that we face a race-to-the-bottom in corporate law. As such, the Bebchuk and Ferrell line of logic represents a significant step toward accepting the conventional state competition race-to-the-top view of corporate law. ${ }^{19}$

${ }^{18}$ We identify two ways in which the addition of another regime choice might, in fact, be harmful. One is the risk that once federal authorities get involved in corporate lawmaking, they may be tempted to make corporate rules mandatory. See infra Part I.B. The other is the potential for confusion and undesirable outcomes stemming from the difficulty of mixing state corporate law with federal takeover law. See infra Part I.C.

${ }^{19}$ Three caveats are appropriate. First, Allen Ferrell has not opposed state competition in print, although a prior article by Bebchuk and Ferrell emphasizes the shortcomings of state competition in corporate law. See Lucian Arye Bebchuk \& Allen Ferrell, Federalism and Corporate Law: The Race to Protect Managers from Takeovers, 99 Colum. L. Rev. 1168, 1170 (1999) ("Our analysis suggests that state competition suffers from inportant structural problems, and that competition among states is therefore hikely to produce troubling results with respect to some critical aspects of corporate law."). Second, Bebchuk and Ferrell's essay does not say that competition in corporate law is a good thing, even in the "choice-enhancing" form they propose. Bebchuk and Ferrell argue only that their proposal is better than the standard form of state competition, not that it is better than mandatory federal takeover regulation. Bebchuk \& Ferrell, supra note 9, at 116 ("While choiceenhancing intervention is superior to federal nomintervention, it might not be superior ... to inandatory federal rules. We do not attempt to resolve in this work which of these two approaches would be preferable."). Third, Bebchuk and Ferrell's proposal imcludes a mandatory procedural rule under which sliareliolders can opt into the federal regime without the approval of the board. It is unlikely that they would 
Of course, Bebchuk and Ferrell argue that their proposal represents more than simply the addition of a fifty-first option. This belief rests on two primary claims. First, they contend that the incentives of the federal government are fundamentally different from those of the states and that a federal regime will, therefore, provide benefits that state regimes do not. They argue that the federal government looks to the interests of all U.S. shareholders and, therefore, would be willing to develop new corporate law rules even if its best innovations are likely to be copied by Delawaregiving corporations no reason to migrate to the federal regime. ${ }^{20}$ The states, in contrast, are unwilling to serve as the stalking horse that forces innovation in Delaware but that does not yield a significant payoff to the innovating state. ${ }^{21}$ Second, their proposal includes the establishment of a new shareholder-only choice rule, allowing for majority vote opt-in to the federal takeover regime. ${ }^{22}$ The claim here is that expanded choice will not reduce shareholder welfare because the procedural rules maike it more likely that corporations will reincorporate only when shareholder value is increased.

By advocating increased choice subject to this procedural change, Bebchuk and Ferrell sign on to the traditional race-to-thetop school of thought subject to the adoption of their procedural rule. Putting aside questions surrounding the shareholder choice rule for the moment, this Part makes the following observations. Section A advances the argument that if Bebchuk and Ferrell's proposal represents a welfare-enhancing strategy, it follows that one can provide even more benefits through an even greater expansion of choice. Section B raises some questions regarding the structural factors that may make a federal takeover regime superior to state corporate law alternatives. Section $\mathrm{C}$ discusses problems with focusing solely on the takeover portion of state corporate law.

support the increase in choice without this procedural rule. Id. at 115 (calling their mandatory procedural rule a "critical" element of their proposal).

${ }^{2}$ In addition, Bebchuk has previously argued that the federal government will take into account external effects on non-shareholder constituencies including creditors, hostile bidders, and employees, among others, from corporate transactions more fully than any individual state. See Bebchuk, supra note 6, at 1485-95.

2 Bebchuk and Ferrell, supra note 9, at 154-55.

"Id. at 147. 


\section{A. Moves Toward Greater Choice}

Start with the assumption that Bebchuk and Ferrell are correct that a federal takeover regime would provide a real alternative to the extant state corporate law regimes. ${ }^{23}$ Given this assumption, the Bebchuk and Ferrell proposal represents an improvement over the status quo, but it may not go far enough. For those who believe in the merits of choice, the Bebchuk and Ferrell proposal certainly dominates a world where companies lack such a choice ${ }^{24}$ but it sets unnecessary limits on the choice available to corporations.

The "choice enhancing" federal takeover regime advanced by Bebchuk and Ferrell represents one point along a continuum of possible choices. To the extent more choice is better, Bebchuk and Ferrell are correct that the addition of a federal choice doninates the present state law competition regime. If choice is better, however, one must also recognize that providing even more choice is better still. So why not open up state law competition all the way to include any source (public or private) of law?

Bebchuk and Ferrell's regime, for example, nıay not dominate an alternative regime conıprised of even greater selection. Imagine, for example, a regime under which U.S.-based corporations may select from a wide range of privately-supplied corporate law rules $\mathrm{m}$ addition to the existing state law options. This is not such a radical notion-most state corporate law rules are voluntary in the sense that corporations may opt out and substitute private contractual provisions. For example, Delaware requires corporations to hold an aumual meeting to elect directors. ${ }^{25}$ Through the articles of incorporation, however, a corporation may opt out of the annual meeting requirenient, electing directors through written consents. ${ }^{26}$

Nevertheless, the existing contractual means of opting out of state corporate law are limited. Corporations may not opt out of all aspects of most corporate law regimes. ${ }^{27}$ For example, corporations may not completely opt out of the fiduciary duties imposed on di-

\footnotetext{
${ }^{23}$ The move from fifty to fifty-one jurisdictions represents a meaningful improvement only if the federal addition is different from the existing state jurisdictions in some significant way.

${ }^{24}$ But see supra note 18 .

25 Del. Code Ann. tit. 8, \& 211 (Supp. 2000).

${ }^{26} \mathrm{Id}$.

${ }^{27}$ Gordon, supra note 8, at 1551-53.
} 
rectors and management. ${ }^{28}$ Moreover, good reasons may exist to limit the ability of parties to adopt private contractual provisions. Professor Jeffrey Gordon, for example, argues that contractual terms suffer from problems relating to the uncertainty of apphication. Mandatory terms force everyone to use the same terms, leading to greater certainty in their application. ${ }^{29}$ Gordon also argues that mandatory terms may result in greater innovation in corporate law terms. When managers engage in innovation, shareholders may question the managers' motives and resist the innovation. Regulators, in contrast, inay more easily convince shareholders of the value-increasing nature of state-sponsored reforms."

An alternative approach is possible that addresses the public goods nature of corporate law terms and the need to encourage innovation in these terms. Federal regulators could assist private parties seeking to provide entire alternatives to the state law corporate regime. Regulators, for example, may allow corporations to select from a menu of corporate law regimes provided through private suppliers. Regulators may announce to the market that, say, five private regimes will be available for selection. Regulators may then auction off the privilege of providing a private regime to the five highest bidders. To the extent the private supphers with the most value for shareholders receive the greatest incorporation fees, they will bid the most for the privilege.

Suppose that Cravath, Swaine \& Moore decides to get into the business of providing wholly crafted sets of corporate law rules, including a set of dispute resolution procedures. If investors value that regime, corporations will pay for the ability to access Cravath's

\footnotetext{
$2 \times$ Id. at $1593-97$.

${ }^{24}$ Id. at 1564-67.

*Id. at 1569-73. Gordon also argues that mandatory terms may solve problems related to opportunistic nidstream shifts toward regimes favoring managers after the initial sale of securities to the public. Id. at 1573-85. Nevertheless, it is unclear why entrepreneurs at the time of the initial incorporation will not select a regime that provides a value-naximizing procedure for inidstream shifts. Nothing requires that the entrepreneurs must allow full freedom in midstream shifts; nor are entrepreneurs limited to simple "freeze" provisions that prohibit all midstream shifts. If a state has a desirable midstream change provision-allowing shareolder-only imitiated charter amendments, for example-entrepreneurs may select such a regime through the voluntary selection of the state for incorporation.
} 
regime and dispute resolution process. Cravath would also benefit through the increased demand for its legal services related to corporate law inatters under Cravath's corporate law regime. Cravath, in turn, would be willing to pay for the privilege of listing its regine as one alternative with an enabling regulator. ${ }^{3 \mathrm{i}}$

The provision of entire corporate law regimes through private vendors has several advantages over the present corporate law regime. First and foremost, the provision of an entire regime acting as a complete alternative to a state's corporate regime addresses both public good and innovation concerns. Because only a limited number of private regimes are available, each regime has the opportumity to develop the scale necessary to provide certainty. Also, because entire regimes are provided, the private supplier may consider the interaction of different aspects of its regime. To the extent private suppliers receive rents in the form of incorporation fees froin their regime, they will also have strong incentives to innovate in a manner that best increases overall sliarelolder welfare. $^{32}$

Second, unlike state regulators, private suppliers of corporate law rules will focus solely on maximizing the surplus from the provision of legal rules. As discussed below, state lawmakers may have objectives that differ from the pure maximization of corporate surplus. In addition, because private suppliers internalize the full benefits from providing value-maximizing corporate law rules, they will have strong incentives to innovate and tailor their rules to market preferences. While state competition focused on incorporation fees may generate some competition, the introduction of private suppliers lias the potential to increase dramatically the competitive pressures facing state lawmakers. Even where corporations choose state corporate law over private suppliers, the

${ }^{31}$ Elsewhere we have discussed the possibility of permitting wide-ranging jurisdictional choice for the issuers of securities. Choi \& Guzman, supra note 3.

${ }^{32}$ Moreover, to the extent that the private supplier develops a credible reputation for providing corporate law rules that maximize shareholder value, thereby increasing its incorporation fee revenue, the private supplier will have a greater ability to innovate in the provision of new corporate law rules. Innovations provided through a reputable private supplier of corporate law rules will be viewed with less suspicion than those provided by a company's management. See supra text accompanying note 31. 
presence of private suppliers will limit the ability of state lawmakers to stray from the outcome that maximizes shareholder welfare.

Third, the expansion of choice to include both a federal takeover regime and private suppliers of entire corporate law regimes dominates Bebchuk and Ferrell's proposal. We are not opposed to Bebchuk and Ferrell's federal option; we only argue that in addition to their choice, regulators should also allow private supphers of regulatory regimes to offer alternatives to corporations. Just as the addition of a federal option cannot harm shareholders where choice leads to the selection of rules that increase shareholder welfare, the addition of private suppliers of corporate law rules camiot harm shareholders.

If the above arguments are correct, there remams the question of why no individual state has stepped forward to act as a facilitator for private corporate law rule suppliers. Any particular state may certainly adopt an enabling approach to private suppliers of corporate law rules, charging corporations a fee to access the corporate law rules of a private source. Several responses are possible. Individual states may not face sufficient competitive pressure to engage in such innovation. As Bebchuk and Ferrell argue, Delaware's ability to mimic other states may chill efforts at innovation. ${ }^{33}$ In addition, public choice concerns may exist. State regulators, for example, may seek to retain control over corporate law to maintain their own individual positions. ${ }^{34}$

Our point here is not that a system of expanded choice is necessarily desirable. Rather, we simply wish to point out that if one accepts Bebchuk and Ferrell's claim that their regime dominates the status quo, it follows that an even greater expansion of choice is better still. Bebchuk and Ferrell may nevertheless argue that not all choices are equal. To the extent a race-to-the-bottom exists, adding more choices may exacerbate that race. A federal option, due to the structural features Bebchuk and Ferrell identify, may provide a "good" choice for shareholders and thus may not have the saine negative effect on a race-to-the-bottom. One response to this argument is that states in fact compete to imcrease shareholder

"Bebchuk \& Ferrell, supra note 9, at 154-55.

${ }^{4}$ Private suppliers of corporate law rules may also face problems in reaching sufficient economies of scale. See infra text accompanying notes 54-56. 
welfare; if this is not the case then even adding a benign choice in the form of a federal takeover regime will not affirmatively improve shareholder welfare unless a procedural rule like the one proposed by Bebchuk and Ferrell is adopted. The claim that federal intervention in the particular form proposed by Bebchuk and Ferrell produces better takeover law from a shareholder welfare perspective than does the existing system of state conpetition can also be challenged. This is the task of the next section.

\section{B. Political Economy and Federal Intervention}

Bebchuk and Ferrell argue that structural features of a federal takeover reginie will generate rules more likely to maximize shareholder welfare than do existing takeover rules. Despite their acknowledgement that a system of choice may provide shareholders with good incentives to select the federal regime, they remain skeptical that this same system of choice will result in competitive pressures to generate good state law rules. In particular, Bebchuk and Ferrell first argue that competition among states will "produce undesirable regulatory choices by the states." ${ }^{35}$ The basic argunient here is that states seek to maximize the number of incorporations within their jurisdictions and, therefore, have an incentive to appeal to managers' interests. This is so because decisions regarding reincorporation are controlled primarily by managers. Without management support for remcorporation, the issue is not subject to a shareholder vote. ${ }^{36}$ Thus, the argument goes, states try to appeal to the interests of managers in an effort to discourage corporations from reincorporating outside the state and to encourage reincorporations within their own state.

The second step in the argument against state takeover law is to show that there exists a divergence between shareholder and manager interests. It is argued that the managers of potential takeover targets prefer to have control over takeover-related decisions because takeovers threaten management jobs. ${ }^{37}$ Even if management

${ }^{35}$ Bebchuk \& Ferrell, supra note 9, at 132 (citing Bebchuk, supra note 6, at 145884).

${ }^{36}$ Bebchuk and Ferrell also point out that managers enjoy some influence over the outcome of a shareholder vote on reincorporation. Id. at 133.

${ }^{37}$ Id. at 134. 
favors the acquisition, the power to block it may give management the leverage necessary to extract private payments from the acquirer. ${ }^{3 \times}$ For this reason, it is argued that the management of a firm values legal protections against takeovers more than do its shareholders.

The above arguments against state competition are well established in the literature, many of them having been developed in earlier work by Bebchuk and Ferrell. ${ }^{39}$ The novel contribution advanced by Bebchuk and Ferrell is their particular proposal for federal intervention. If one accepts that their concerns regarding state competition are well placed, two additional facts must be established before one can support federal intervention. First, it inust be shown that the adoption of federal takeover law promises to be different from what is currently done by states. That is, it must be established that federal law will serve the interests of shareholders rather than managers. Second, it must be shown that a federal law can establish itself, gam scale economies, and thereby offer a real choice to firms.

Conventional objections to federal intervention in the corporate law market are based on fears that federal rules will generate worse results than state rules. The tradeoff that has existed in the literature up to this point has been between inandatory federal rules-promoted on the grounds that they lead to the internalization of the third party effects related to the selection of corporate law rules-and the existing state-based system-defended on the grounds that competition among states leads to the adoption of good laws. Most commentators concede that the state law generated by competition for charters is imperfect, but they inaintain the view that it is better than the federal alternative. ${ }^{40}$

\footnotetext{
* Id.

${ }^{34}$ See, e.g., Bebchuk, supra note 6 (arguing for federal intervention to correct problems with state competition).

"See Easterbrook \& Fischel. supra note 3, at 222 ("If the clain is that the competition among states for incorporations always produces the optimal result, it stands refuted. But if the thesis is that competition creates a powerful tendency for states to enact laws that operate to the benefit of investors ... it is alive and well."); Romano, Genius of American Corporate Law, supra note 3, at 75 ("Acknowledging that the track record of most states in takeover regulation raises serious questions concerning the efficacy of state coinpetition does not imply that national regulation of takeovers is the solution to an imperfect federal system.").
} 
One of the most persuasive arguments against federal intervention has been advanced by Professor Roberta Romano. ${ }^{41}$ She points out that federal legislation is no more immune from the political economy of corporate law than are state lawmakers. Even if the rules are federalized, managers represent a more concentrated group than do shareholders and, therefore, are better able to lobby the government for their preferred legislation. ${ }^{42}$ If one accepts that the federal government, like the states, is affected by the political power of managers, the use of mandatory federal rules may be worse than reliance on state rules because competition among the states will, at a minimum, constrain the ability of lawmakers to provide pro-manager rules.

Unlike past proposals for federal intervention, however, the Bebchuk and Ferrell proposal does not call for mandatory federal rules, and it is therefore at least partially insulated from Romano's argument. Competition with state takeover regimes will restrain the ability of federal regulators to adopt value-reducing takeover provisions.

Whether one believes that state competition is harmful or that it is beneficial, one is likely to feel that the proposed clioice enhancing intervention is imperfect. Where competition results in a raceto-the-top, Bebchuk and Ferrell's proposal is too narrow, nnissing other ways of expanding choice. On the other hand, to the extent a race-to-the-bottom exists, Bebchuk and Ferrell are too confident in the ability of a federal regime to produce takeover rules that benefit shareholders rather than managers.

Bebchuk and Ferrell make the point that a federal regulator will take into account different interests than will a state regulator. ${ }^{43}$ The inost important distinction identified by Bebchuk and Ferrell relates to the question of innovation and change in corporate law regimes. They argue that a state may be unwilling to innovate with respect to its corporate law because those imovations, should they

\footnotetext{
${ }^{41}$ See Roberta Romano, Future of Hostile Takeovers (1988); Romano, Genius of American Corporate Law, supra note 3.

${ }^{42}$ Romano, Genius of American Corporate Law, supra note 3, at 75-76.

${ }^{43}$ Bebchuk \& Ferrell, supra note 9, at 151 ("The additional player we propose, however, would be a different type of player with different incentives from the typical state ....").
} 
prove successful, can simply be copied by Delaware. ${ }^{44}$ The innovating state "serve[s] as the stalking horse to get Delaware to do what is good for shareholders, but would not gain itself." ${ }^{\text {"45 }}$ The federal government, it is claimed, is subject to a different set of incentives. It looks to the interests of all U.S. shareholders and is therefore willing to undertake an investment in the development of a new corporate law regime even if the benefits go to Delaware. ${ }^{46}$

The argument in favor of a substantive federal takeover law, therefore, hinges on the claim that the federal government is less influenced by the return it receives in the form of incorporation fees than are the states. ${ }^{47}$ There are several reasons to doubt that the federal government will behave in the benign fashion outlined by Bebchuk and Ferrell. Furthermore, if it is true that the federal government is committed to the pursuit of shareholder welfare rather than increasing participation in the federal system, the federal regime may be insufficiently responsive to the discipline of competitive forces.

First, consider a federal regulator that ignores the benefit from incorporation revenues in designing federal takeover-related law. ${ }^{48}$ Once the federal government establishes an administrative body to oversee the federal takeover regime, public choice problems may arise. Under a federal shareholder opt-in takeover regime, the public choice pressure will be especially intense. Lobbyists, for example, will focus on the federal regime because, unlike state regimes, the federal rules are potentially relevant for every firm in the nation. ${ }^{.19}$ Capture of federal regulators has the potential to pro-

$\$ 4$ Id. at 154-55.

"Id. at 155.

* Id.

*7 Id. ("The federal government would be more likely to look to the aggregate interests of U.S. shareholders and companies and would not feel the same need to make a return on investment in developing an alternative takeover regime.").

* The revenues, for example, may go into the general treasury rather than to the regulatory agency.

${ }^{49}$ On the other hand, in an earlier article Bebchuk argued that managers may enjoy a greater ability to lobby state law officials compared with federal regulators due to the lack of resources of state legislators. See Bebchuk, supra note 6, at 1503 \& n.204 (citing Roberta Romano, The Political Economy of Takeover Statutes, 73 Va. L. Rev. $111,133,145(1987))$ ). It is unclear, however, whether federal regulators would in fact enjoy a resource advantage compared with Delaware. To the extent Delaware already obtains significant revenues from franchise taxes and fees, Delaware officials may 
vide special interest groups with a much larger payoff than would the capture of any single state with the possible exception of Delaware. Federal regulators, therefore, may choose to adopt a system that mcludes managerial protection even if a different regime would lead to greater benefits for shareholders. Moreover, if the federal government is imsulated from the pressure to attract incorporations, the federal agency implementing a takeover-related corporate law regime may not adapt well to change. The regulatory competition model relies on the pursuit of incorporations to guide the competing jurisdictions. If the federal government is guided by other concerns, it is difficult to know how it would select its rules and how it would judge their success.

Second, in the alternative, competition from state takeover law regimes may in fact provide a disciplining effect on federal regulators. A federal corporate law regulatory agency may benefit from mcreased incorporation fees that remain within the agency. To the extent increased incorporations warrant a larger bureaucracy, federal regulators may also benefit from the greater prestige and power accompanying such a bureaucracy. Where federal regulators are in active competition with state corporate law, however, administrators within a federal regime are likely to be influenced by the same forces that affect state decision makers. Like any other jurisdiction, a federal administrative agency given the task of framing rules and managing the system is likely to want to maximize the number of firms subject to federal rules (for both fees and prestige). ${ }^{50}$ The decisions of these bureaucrats will be based on criteria that are essentially identical to those facing state corporate law decision makers. Policies that offer the potential of attracting more incorporations will be favored over those that do not. Policies that promise no observable change in the number of incorporations will not serve the interests of any administrators and, as a result, will not be implemented. Federal regulators, therefore, will face the same stalking horse problem as do the states. Federal regulators will not wish to expend resources developing a new innovative

have a greater ability to gather information on proposed corporate law changes than would officials with a new federal corporate law agency.

so See, e.g., Gary S. Becker, A Theory of Competition Among Pressure Groups for Political Influence, 98 Q.J. Econ. 371 (1983); George J. Stigler, The Theory of Economic Regulation, 2 Bell J. Econ. \& Mgınt. Sci. 3 (1971). 
regulatory scheme if Delaware can simply mimic the system. If the process rule proposed by Bebchuk and Ferrell works as they hope, it is true that federal regulators will have an incentive to appeal to shareholders rather than managers. The same is true, however, of states, once again bringing into question the benefits of a separate federal regime.

Federal rulemaking presents one additional problem. There is a danger that a federal agency will eventually mcrease the scope of its laws and, perhaps, make them mandatory. Faced with a desire to attract incorporations, and recognizing that their professional success is heavily influenced by their ability to do so, federal administrators can be expected to use whatever powers they have to attract firms. Unlike the states, however, the federal government has the ability to make its rules mandatory. From the perspective of federal administrators, making federal rules mandatory may seem like an effective way of winning the regulatory competition game. That the competition itself is desirable may be lost on them. The SEC, for example, attempted to imcorporate aspects of corporate law into its disclosure regime in the mid-1980s. Under the original Securities Exchange Act of 1934 Rule 19c-4, the SEC prohibited deviations from one-share, one-vote division of voting power within a corporation in response to dual class recapitalizations that had the effect of increasing the voting power of shares friendly to incumbent managers. ${ }^{51}$ In Business Roundtable v. $S E C$, the D.C. Circuit struck down Rule 19c-4 as going beyond the SEC's statutory powers. ${ }^{53}$ Nevertheless, Business Roundtable provides an example of a federal agency seeking to expand into state corporate law. Once it is given a foothold in the corporate law arena, a federal agency seeking to expand its own power and prestige may face irresistible incentives to expand to other areas of corporate law or to make its existing rules mandatory.

"See Jonathan R. Macey, Administrative Agency Obsolescence and Interest Group Formation: A Case Study of the SEC at Sixty, 15 Cardozo L. Rev. 909, 937-39 (1994). In the article. Professor Macey argued that the SEC is obsolete. One characteristic of an obsolete agency. he argued, was that it tends to seek out new avenues of regulation to provide an ongoing justification to remain in existence. Id. at 912-14.

$\because 905$ F.2d 406 (D.C. Cir. 1990).

"Id. at 407. 
The problem for a federal regime is that it must walk a narrow path between being indifferent or insulated from competition-in which case it is unlikely to be popular or important (and in the worst case scenario nay be captured by managers)-and being driven by competition-in which case it offers no benefits over state regimes and carries the risk that federal administrators may seek to expand their authority or make their regime mandatory.

\section{Economies of Scale and Divisibility in Corporate Law}

The transition from the status quo to a system with a federal takeover law presents additional problems for the Bebchuk and Ferrell proposal. Economies of scale matter in corporate law. The more users of a particular regime there are over time, the more certain the laws become and therefore the greater its value to shareholders. ${ }^{54}$ Bebchuk and Ferrell acknowledge this point and use it to argue that states such as Montana have no hope of overtaking Delaware as a leading provider of corporate law rules. ${ }^{55}$ The same argument, however, inay also be apphied to a new federal corporate law regime. Indeed, individual states have the advantage that im-state entities have a bias toward incorporating within their hoine state. Home state incorporation provides companies the benefit of familiarity, the ability to use local attorneys, and often lower legal fees. ${ }^{56}$ Such local incorporations, in turn, generate a certain level of certainty and confidence in the system. A federal regime, on the other hand, has no such natural advantage to obtain incorporations. Such a new regime, therefore, may not obtain the necessary scale to make it attractive for corporations to select, even if it offers attractive substantive rules.

The Bebchuk and Ferrell proposal also suffers from the narrow scope of the proposed federal corporate law regime. In particular,

\footnotetext{
${ }^{54}$ Marcel Kahan \& Ehud Kamar, Price Discrimination in the Market for Corporate Law 10 (Sept. 22, 1999) (unpublished manuscript, on file with the Virginia Law Review Association). Scale economies derived as more users adopt a particular corporate law rule, in turn, may give rise to network externalities. See Michael Klausner, Corporations, Corporate Law, and Networks of Contracts, 81 Va. L. Rev. 757, 762-63 (1995).

ss Bebchuk \& Ferrell, supra note 9, at 154-55.

${ }^{56}$ Ehud Kamar, A Regulatory Competition Theory of Indeterminacy in Corporate Law, 98 Colum. L. Rev. 1908, 1935-37 (1998).
} 
the proposal's focus on antitakeover laws leaves open the possibility that coordination problems may arise between different regimes. Some firms may select the entire Delaware regime. Others may select the Delaware regime for all but the takeover law provisions, choosing to substitute the federal takeover regime. The overlap of regimes threatens to generate several negative consequences.

First, the scope of a federal takeover regime may be uncertain, forcing adopters to bear the uncertainty of whether federal or state law applies to particular questions. These uncertainty costs include not only the cost imposed by the fact that the parties cannot be certain of the applicable law, but also costs imposed by the strategic behavior of the parties. For example, the applicable law may well depend on the court in which a suit is brought. In a close case, for example, Delaware courts would be more likely to apply Delaware law over federal law than would federal courts. This scenario generates a race to the courthouse that accelerates litigation and wastes resources as the parties fight over the choice of forum and law. Furthermore, parties involved in litigation would have an incentive to make federal claims in their complaints-including spurious ones-if they anticipate that federal rules (whether substantive or procedural) are favorable to their cause.

Second, federal corporate regulators may face constraints on their ability to innovate in ways that diverge from present takeover law. Corporations that seek to maximize shareholder value will have an incentive to select the combination of investor protections that achieve that goal. Thus, if a combination of federal takeover law and general Delaware corporate law maximizes share value, companies will select such a combination. To the extent the federal regime does not interact well with other aspects of state corporate law, companies will stay away froin the federal takeover option. For example, a state may design a regime to control managerial opportunism through a carefully weighed balance of stringent fiduciary duty requirements, including the ehimination of a demand requirement for shareholder derivative suits, and takeover rules allowing for powerful defensive tactics. The selection of a federal regime that prohibits all but weak takeover defenses may upset the balance provided under the state regime, rendering the stringent fiduciary duties against managerial opportumism potentially redun- 
dant and excessively costly. The necessity of creating a regiune complementary with existing state non-takeover corporate law provisions may therefore limit the value of the federal takeover regime option.

Third, even if federal lawmakers craft the federal takeover provisions to complement a particular state's corporate law regime, the takeover provisions may not interact well with aspects of corporate law in other states. Federal lawmakers, for example, may craft takeover provisions that fit well with Delaware law, but such provisions may not complement Nevada law. To the extent corporate law at its component level is not fully interchangeable, the federal government must choose to favor a subset of the state law regimes, most likely including Delaware as the inost popular state regime. This would result im an additional advantage for Delaware, reducing competition among the states for non-takeover-related provisions.

Finally, if the problem of integrating multiple state regimes with the federal regime is sufficiently serious, states may find that they have to adjust their own rules to accommodate the federal regime. As a result, there is a risk that the federal regime will homogenize some aspects of corporate law, actually causing a reduction in the choice available to corporations.

Bebchuk and Ferrell attempt to address the problem of scale economies and divisibility, at least with respect to the adjudication and enforcement of federal takeover law. ${ }^{57}$ They suggest, for example, that the parties to a dispute involving federal takeover law would have the option of using Delaware's Chancery Court, which offers an experienced and respected judicial system along with a well-developed and widely read body of precedent. Such an approach is, of course, problematic when the two parties disagree on the preferred forum. If the takeover law is federal, the party preferring federal courts will be able to remove the case froin state court. An alternative proposal discussed by Bebchuk and Ferrell is to create a federal court that will specialize in corporate law questions. ${ }^{58}$ Over timie, they predict, this court would develop some of the advantages of experience and consistency enjoyed by the

$\Im$ Bebchuk \& Ferrell, supra note 9 , at $145-47$.

ss Id. at 146. 
Delaware Chancery Court. This solution resolves the long-term problem of having federal takeover matters being decided by normal federal courts where it would be difficult to achieve the level of confidence and certainty that exists in the Delaware system. It does not, however, explain how the federal system will attract enough corporations to build up this body of precedent. Nor does a separate federal court address the forum-shopping problem that is inherent in a system with overlapping jurisdiction.

\section{The Shareholder-OnLy OPT-IN RULE}

The procedural rule advocated by Bebchuk and Ferrell consists of a mandatory voting procedure through which a majority of shareholders (acting without board approval) can choose federal takeover rules rather than those of the state in which the corporation is incorporated. Shareholders can vote in a similar way to exit the federal scheme and return to state rules. These votes would be binding on the corporation. ${ }^{60}$ By giving shareholders the ability to opt into or out of the federal rules, it is reasoned that regulators can ensure that shareholder preferences are respected and managers are unable to hide behind excessively protective takeover rules. The shareholder-only opt-in rule ${ }^{61}$ represents a critical part of their position because without it the federal regime cannot address the problem of management control of reincorporation decisions.

A structurally similar proposal has been advanced by Professors William Bratton and Joseph McCahery, who argue that the federal government should impose a mandatory choice rule giving shareholders the ability to amend the corporate charter by majority vote. ${ }^{62}$ Under the Bratton and McCahery proposal, a shareholder

${ }^{\prime}$ In addition to the above issues, there is a potential constitutional problem with the establishment of a federal corporate court unless it is made an Article III court under the U.S. Constitution, a move which would surely face substantial opposition from the judiciary and others. See N. Pipeline Constr. Co. v. Marathon Pipe Line Co., 458 U.S. 50,59 (i982).

a) Bebchuk and Ferrell leave to one side some of the specifics of their plan, including the procedure by which shareholders would force a vote on takeover rules. Bebchuk \& Ferrell, supra note 9, at 143. We follow their lead and leave these issues for another day.

${ }^{\circ 1}$ Id. at 147-49.

${ }^{62}$ William W. Bratton \& Joseph A. McCahery, Regulatory Competition, Regulatory Capture, and Corporate Self-Regulation, 73 N.C. L. Rev. 1861, 1926 (1995). 
proponent initiates a resolution to mandate a committee of independent directors to recommend an alternative state of imcorporation. ${ }^{63}$ The next year, shareholders vote on whether to approve or reject the move to the proposed alternative jurisdiction. $^{64}$ This Part first discusses the necessity of making a shareholder opt-in rule mandatory. We then analyze whether a shareholder opt-in rule is good for shareholder welfare by discussmg its iniphications for state corporate law.

\section{A. The Voluntary Nature of the Mandatory Process Rule}

Although we agree that a procedural shareholder opt-in rule may have some merit, we do not believe that it should be made mandatory. If it is value-increasing, firms have an mcentive to voluntarily mstall a shareholder opt-in provision as part of their own internal corporate regime. Likewise, states seeking to attract firms at the initial stage of incorporation will adopt shareholder opt-in provisions $\mathrm{m}$ their state corporate law regimes. Bebchuk and Ferrell concur with this reasoning, stating that shareholders can opt out of their "mandatory" process rule by so specifying in their charter. ${ }^{65}$ In this section we consider the question of whether an optional opt-im rule is likely to yield significant benefits.

It is helpful at this point to identify two different categories of public firms. Consider first firms that are going public for the first tinie. Such initial public offermg ("IPO") firms will have strong incentives to select regimes that maximize the total value of the company ${ }^{66}$ At the tine of the initial incorporation, these firms will select the takeover regime that maximizes value. ${ }^{67}$ For these firms,

${ }^{63}$ Id. at 1939 . Bratton and McCahery's proposal would require the committee of independent directors to seek the advice of an outside consultant. Id.

${ }^{6}$ Id.

os Bebchuk \& Ferrell, supra note 9, at 148. Throughout Bebchuk and Ferrell's essay, references are made to the "mandatory process rule." E.g., id. at 113. In the interests of clarity, we have used the same language in our Essay.

6 Jensen \& Meckling, supra note 4.

${ }^{67}$ But see Robert Daines \& Michael Klausner, Do IPO Charters Maximize Firm Value? Antitakeover Protection in IPOs 4, 28 (Stanford Law School, John M. Olin Prograin in Law and Economics, Working Paper No. 184, 1999), available at http://papers.ssrn.com/papers.taf?abstract_id=187348 (concluding that antitakover provisions remain common at the IPO stage and that they are explained by manageinent entrenchment). 
then, there is no need for a mandatory shareholder opt-in rule. If such a rule is value maximizing, it will be adopted by the firm at the time of the initial public offering.

What Bebchuk and Ferrell are really concerned about-and where their argument applies most forcefully-is the group of firms that were already public and that experienced a dramatic change in the background takeover regime during the 1980s. ${ }^{68}$ The Bebchuk and Ferrell proposal is directed primarily at these existing firms, especially those that were in existence before the invention of the poison pill. As Bebcluuk and Ferrell state in their essay, "[t]lle development and implementation of the poison pill defense in the 1980 s was a midstreain change in the fundanental structure of the corporation that was accomplislied not by sliareholders approving the defense, but ratler by state law giving management the unilateral power to do so...." The claim is that the shareholders of corporations that were in existence before the advent of the pill did not choose to adopt that defense. Ratlier, tlie development of such powerful antitakeover provisions ("ATPs") represented an unanticipated change in the landscape of corporate law. If this change in the legal landscape was unanticipated, it follows that the original shareholders did not take it into account when they purchased shares at the IPO stage. Legal intervention to undermine tlie effectiveness of the pill, according to this view, does not represent a frustration of shareholder choice but rather protects the choice made by shareholders at the IPO stage. The procedural rule proposed by Bebchuk and Ferrell, therefore, is intended to address a problem with inidstream slifts that took place as a result of the pill.

If one accepts that the poison pill is as harmful as Bebchuk and Ferrell believe, the above argument is a compelling one. ${ }^{70}$ The claim, however, addresses only a subset of all incorporated firms. It is only shareholders of firms that were incorporated before the advent of the pill that can be said to liave been "fooled."

Bebchuk \& Ferrell, supra note 9, at 117-28.

${ }^{\circ}$ Id. at 123.

") This argument remains subject, however, to concerns about the form of legal intervention and its costs relative to the costs of the status quo.

${ }^{71}$ Even these firms face a certain amount of market discipline because they may wish to return to the capital inarkets in the future. Altlough the potential future need to raise money is an imperfect way to discipline firms, it does provide some constraint. 
Shareholders of firms incorporated since the poison pill was invented have been on notice that the pill exists and, indeed, have known that the pill can be adopted by a managenent team at any time in order to fight off a takeover attempt. ${ }^{2}$ At the time of their IPO, therefore, these shareholders were in a position to include the impact of the poison pill in their pricing of securities.

If shareholders are able to price the value of the pill and other ATPs at the IPO stage, one would expect firm charters to be written in such a way as to nnaximize firm value. ${ }^{73}$ If the poison pill or other antitakeover devices reduce the value of the firin, one would expect these firms to adopt charter provisions restricting the use of these devices or forbidding them altogether. ${ }^{74}$ In fact, if the Bebchuk and Ferrell proposal is desirable, firms could adopt it directly in their corporate charters. They could not, of course, include a set of federal takeover rules, but they could include provisions for the opting out of state takeover laws or reincorporation in another state based solely on a shareholder vote. ${ }^{75}$ Similarly, corporations could specify a set of rules to govern takeover defenses. A corporation, for example, could prohibit the use of shareholder rights plans-the typical mechanism for a poison pillin the corporate charter.

Bebchuk and Ferrell's arguments against the poison pill, however, do not address the question of what new firms have done with their corporate charters since the invention of the pill. Although Bebchuk and Ferrell offer some evidence suggesting that ATPs are harmful-especially the poison pill combined with classified boards-they do not suggest that corporate charters tend to ban such devices. Instead, they describe other measures that have been taken in an effort to prevent manager misconduct, including a reduction in the frequency with which we see classified boards. ${ }^{76}$

\footnotetext{
${ }^{2}$ See Robert Comment \& G. William Schwert, Poison or Placebo? Evidence on the deterrence and wealth effects of modern antitakover measures, 39 J. Fin. Econ. 3, 5-7 (1995); Dames \& Klausner, supra note 67, at 7.

${ }_{3}$ Jensen \& Meckling, supra note 4.

${ }^{74}$ Dames \& Klausner, supra note 67 , at 3.

${ }^{75}$ See supra note 14 (discussmg the ability of firms to adopt a shareholder-only reincorporation procedure in the corporate charter).

${ }^{76}$ Bebchuk \& Ferrell, supra note 9, at 125 ("[M] ost classified boards were adopted prior to 1990 , before it became clear that courts would almost always allow managers to keep a pill in place indefinitely ...."); id. at 126-27 ("[W]hile many companies that
} 
The point here is that if Bebchuk and Ferrell are right that the legal innovations of the 1980s reduced the value of existing firms, one would expect firms that have incorporated since that time to have adopted charter provisions in response to those changes. Existing einpirical evidence, however, suggests that ATPs are common at the IPO stage." In a recent paper, Professors Robert Daines and Michael Klausner report that a significant fraction (49.9\%) of compamies conducting an initial public offering contain classified boards and dual class voting structures among other antitakeover charter provisions. ${ }^{78}$ On the one hand, such evidence may point out that firms even at the time of the initial public offering do not maximize firm value. On the other hand, efficiency reasons may justify the use of an ATP even at the time of the initial charter. It may be that these statutes and ATPs protect shareholders from coercive tender offers by providing bargaining power to firn management. ${ }^{79}$ It has also been shown that ATPs inay serve to reduce managerial myopia." Finally, firms inay have inanagers whose firm-specific investinents in hunan capital are important for firm value. Such managers may choose not to make firm-specific investments unless they are assured of longevity with the firm as well as the ability to reap profits once the firm does well. An antitake-

have gone public in the 1990s have classified boards, many do not.... [C]ompanies that did not already have classified boards at the start of the 1990s have found it practically impossible to get the necessary shareholder approval ....").

7 See Daines \& Klausner, supra note 67, at 16 (reporting that, in a sample of over 300 recent-IPO firms, over fifty percent had adopted ATPs, that none of the firms had adopted anti-ATP provisions, and that only $5 \%$ of firms had opted out of the state antitakeover statute); Laura Casares Field, Control Considerations of Newly Public Firms: The Implementation of Antitakeover Provisions and Dual Class Shares Before the IPO 37 (Feb. 1999) (unpublished manuscript, on file with the Virginia Law Review Association) (reporting that, in a sample of over one thousand recent-IPO firms, almost $50 \%$ had adopted ATPs).

${ }^{7}$ See Daines \& Klausner, supra note 67, at 16.

${ }^{7}$ See Harry DeAngelo \& Edward M. Rice, Antitakeover Charter Amendments and Stockholder Wealth, 11 J. Fin. Econ. 329, 342 (1983); Rene M. Stulz, Managerial Control of Voting Rights: Financing Policies and the Market for Corporate Control, 20 J. Fin. Econ. 25, 25-26 (1988); Luigi Zingales, Insider Ownership and the Decision to Go Public, 62 Rev. Econ. Stud. 425, 440 (1995). The notion here is that antitakeover statutes and ATPs protect shareholders from a collective action problem in which they might be forced to tender for below market prices. The statutes and ATPs force the bidder to negotiate with the target's board.

* See Jeremy C. Stein, Efficient Capital Markets, Inefficient Firms: A Model of Myopic Corporate Behavior, 104 Q.J. Econ. 655, 668 (1989); Jeremy C. Stein, Takeover Threats and Managerial Myopia, 96 J. Pol. Econ. 61, 75 (1988). 
over provision may, in turn, provide such managers with the necessary reassurance to engage in firm-specific investments.

That firms at the IPO stage do not appear to shun classified boards and that they do not appear to prevent the use of antitakeover provisions ${ }^{81}$ is troubling for the Bebchuk and Ferrell proposal because their proposal is a default rule rather than a mandatory rule. Bebchuk and Ferrell write: "The process rule would only be mandatory in the sense that regardless of state law, shareholders would have the option, if they did not forego it in their charter, to have their corporation opt into or out of the federal takeover regime." $\$ 2$ If, as the evidence appears to show, corporations are not currently doing all they can at the IPO stage to prevent the use of ATPs, it seems likely that they will take the opportunity to opt out of the Bebchuk and Ferrell process rule at that same stage. We suspect that introducing a different default rule is insufficient to undermine the use of ATPs.

\section{B. Problems with Shareholder Choice}

The central theme of Bebchuk and Ferrell's proposal is a reliance on shareholders to vote in their collective best interest. Therefore, even if Bebchuk and Ferrell are correct when they argue that the shifts in antitakeover doctrine that occurred in the 1980s were wholly unanticipated and never approved by shareholders, ${ }^{84}$ they do not explain why firms tapping capital markets for the first time do not grant shareholder voting rights of the sort envisioned in their proposal.

There are several points of concern with respect to shareholder majority voting as a mechanism to generate choices that maximize shareholder welfare. Indeed, as Professor Jeffrey Gordon has argued, the absence of a shareholder-only choice rule is not new. ${ }^{85}$ Rather, absolute delegation of power to nianagement for publicly-

${ }^{81}$ See supra note 77.

2 Bebchuk \& Ferrell, supra note 9, at 148.

$\$$ See supra note 13 (discussing the importance of the default rule).

${ }^{84}$ See supra notes $68-69$ and accompanying text.

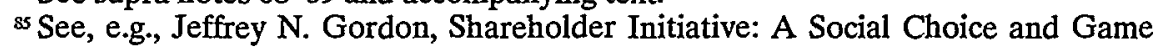
Theoretic Approach to Corporate Law, 60 U. Cin. L. Rev. 347, 348-52 (1991). 
held corporations has long been the norm ${ }^{86}$ First, shareholders face well-known collective action and rational apathy problems. ${ }^{87}$ Lacking good information, shareholders may vote simply according to management's recommended position. To the extent many shareholders simply choose not to vote, managers with significant non-control block positions may disproportionately influence the outcome of a reincorporation vote.

Second, large block shareholders may act opportunistically. A large block shareholder may, for example, identify a particular state law regime that reduces overall share value and threaten to initiate a campaign to shift to such a regime unless management "pays off" the block shareholder. Such a threat is possible to the extent other shareholders lack information and may vote along with the large block shareholder. The large block shareholder may also have a repeat player incentive to maintain a reputation of engaging in such tactics to enhance the credibility of its threat to managers. Managers seeking to nnaximize firm value may then agree to pay off the large block shareholder.

Third, management intent on acting opportunistically still do so even when shareholders alone control the reincorporation process. Managers, for example, may identify and "bribe" large block shareholders with a transfer of value from the corporation. ${ }^{88}$ Once bribed, the large block shareholder may agree not to monitor the managers as closely and to vote along with the managers to approve self-dealing transactions that benefit managers at the expense of the shareholders.

Fourth, even rational shareholders may fall subject to "vote cycling." ${ }^{89}$ That is, the individually rational preferences of a group of shareholders can generate collectively irrational preferences. ${ }^{90}$

so ld. at 358. Gordon observes that once initial investors take into account the impact of absolute delegation of authority to management, they will price such delegation into the share price. Entrepreneurs interested in maximizing their wealth, therefore, will have an incentive to maximize the value to such investors. The lack of a shareholder-only choice rule therefore is evidence that such a rule is not wealthmaximizing for shareholders. ld.

"7 Clark, supra note $12, \$ 3.1 .1$, at 94 .

* For a law and economics analysis of "bribes" made by managers to large block shareholders, see Stephen Choi \& Eric Talley, Playmg Favorites with Shareholders (Working Paper, 2001) (unpublished manuscript, on file with the author).

k* Gordon, supra note 85 , at 359-63. 
Our point is not that shareholder voting is always ineffective as a means of protecting the interests of shareholders. Rather, the effectiveness of shareholder voting may vary depending on the particular circumstances of a firm. The chance of vote cycling, for example, depends on the range of potential policy choices presented to shareholders and the diversity of shareholder preferences. ${ }^{91}$ Care must therefore be taken in proposing a departure from the norm (developed within the competitive state corporate law system) of requiring both board of director approval and a majority shareholder vote to shift the corporate law regime through reincorporation. Even where such a depature is warranted, it is unclear whether a one-size-fits-all or a more nuanced approach to providing shareholder choice is superior. Moreover, firms will have better information with which to select the optimal shareholder choice regime for their specific situations than will a federal regulator.

\section{Expanding Shareholder Choice?}

Bebchuk and Ferrell critique existing takeover law on the grounds that it permits excessive protection for incumbent managers without adequate shareholder control. Here we switch gears and put aside our skepticism regarding the claim that shareholder voting leads to choices that maximize shareholder welfare. We remamed puzzled, however, that Bebchuk and Ferrell place such heavy emphasis on the substantive federal takeover regime option. Although more choice, in our view, is always better, by far the more important part of Bebchuk and Ferrell's contribution is not

\footnotetext{
${ }^{90}$ For example, consider three shareholders: $A, B$, and $C$. $A$ has the following preferences: $1>2>3$. $B$ has the preferences: $2>3>1$. And $C$ has the preferences: $3>$ $1>2$. In such a situation the three shareholders will vote 1 over 2 . They will also vote 2 over 3 . Finally, they will vote 3 over 1 . As a group, therefore, the three shareholders lack transitive preferences. Instead, the choice the group selects depends solely on the voting agenda presented to them. See id.; see also Richard D. McKelvey, Intransitivities in Multidimensional Voting Models and Some Implications for Agenda Control, 12 J. Econ. Theory 472, 480-81 (1976) (arguing that agenda control can affect the voting outcome).

${ }^{91}$ See Gordon, supra note 85, at 364. For example, to the extent shareholders are unanimous in their preferences-to maximize share value, for example-vote cycling is not a problem. Id. at 368. Shareholders, nevertheless, may have different time preferences and lack complete markets to shift payouts between time periods. See id. at 368-69.
} 
the introduction of a fifty-first takeover regime but rather the mandatory process rule. ${ }^{22}$ While a fifty-first choice expands incrementally on the prior fifty choices, the mandatory process rule (assuming our earlier criticisms are unwarranted) holds the promise of unlocking greater competition among all available regime choices.

Even if one assumes that Bebchuk and Ferrell are correct and that their proposal would succeed in providing appropriate takeover rules (whether at the federal or state level), the development of substantive federal takeover rules, while valuable, is not as important as the mandatory process rule. Indeed, we argued earlier in the Essay that a federal takeover option represents simply one of several possible additions to the present set of takeover regimes (and may fall subject to public choice objections). Allowing shareholders to opt into or out of any state takeover law, on the other hand, may dramatically increase shareholder power. Rather than choosing between a single state law and federal law, shareholders would be able to choose from among fifty state takeover laws. ${ }^{93}$

Therefore, proponents of the Bebchuk and Ferrell approach may wish to reduce their focus on the federal takeover option and, instead, pursue the shareholder mandatory process rule with two changes. First, the choice rule could be expanded to include the option to reincorporate into any one of the fifty states' takeover regimes. Second, as discussed earhier, the choice rule may be expanded beyond takeover provisions to include the entire state corporate law regime.

Allowing shareholders to choose any state law would not only increase the number of available choices, it would ensure that shareholders get the substantive takeover law they prefer. Providing choice among all state laws would generate much more competition among jurisdictions seeking to attract corporations. ${ }^{94}$

"In faimess, and as Bebchuk and Ferrell point out, if the procedural claims advanced in their essay are accepted, the authors have done much to advance the debate on corporate takeover law, even if the substantive federal rule is judged to be unnecessary. Bebchuk and Ferrell, supra note 9, at 154.

${ }^{97}$ Bebchuk and Ferrell argue that federal rule makers face different incentives than their state counterparts. Id. at 151-55. We discussed this claim and our reservations about it in Part I.B.

We have some misgivings about permitting the sort of mix and inatch corporate law that Bebchuk and Ferrell propose. These concerns are put aside here in order to 
As a result of this competition, each state would tailor its takeover law to what it beheves shareholders prefer..$^{95}$ The market and the states, then, would do what Bebchuk and Ferrell want the federal government to do-provide the takeover regime that is preferred by shareholders.

Bebchuk and Ferrell anticipate this criticism and argue that even if there is competition among states, no state has an incentive to expend the costs required to provide innovations in corporate law because Delaware will be able to copy those innovations, leaving the first state with the costs and no benefits. ${ }^{96}$ We offered our concerns regarding this "stalking horse" argument earlier in this Essay. ${ }^{97}$ In essence, we are not convinced that the federal government can be expected to simultaneously care about its competition for incorporations with state regulators enough to ensure that it appeals to the needs of shareholders, yet remain sufficiently indifferent to that competition for it to willingly serve as Delaware's stalking horse. It seems more likely that the federal government will compete for busmess-in which case it will face incentives to innovate that are similar to those of the states-or it will not be concerned about the competition, in which case it is unlikely to offer an attractive set of rules.

It is possible to justify the focus on substantive federal takeover law in Bebchuk and Ferrell's proposal, if one believes that shareholders will make poor choices. We have discussed several reasons to worry that shareholders acting as a group may fail to make choices in their own collective best interest. Bebchuk and Ferrell also present one reason why shareholder choice may be undesirable. They state that shareholder choice might lead to an overly restrictive takeover regime because in assessing a takeover bid, shareholders do not take into account the gain to the hostile bid-

emphasize that even one who supports the Bebchuk and Ferrell proposal should prefer eliminating the substantive federal law component. Our views on permitting corporations to choose some elements of corporate law from one jurisdiction and the rest from another are outlined im Part I.C.

${ }^{95}$ The motivation for seeking to have one's corporate law apply to as many corporations as possible would presumably be the same as the motivation for seeking to attract corporate charters: fees, prestige, and power, as addressed in Part I.B.

${ }^{6}$ Bebchuk \& Ferrell, supra note 9, at 154-155.

${ }^{n}$ See supra Part I.B. 
der. ${ }^{\text {.* }}$ If one believes that this is a sufficiently grave problem, one could support federal intervention.

The problem with this justification, of course, is that it also fails to support Bebchuk and Ferrell's proposal that relies on shareholder choice. Rather, only mandatory federal takeover law without an opt-out provision will protect shareholders from their own poor choices. That is, if shareholders cannot be trusted to make the right decision on takeover law, the answer is to provide a mandatory federal law rather than a federal option which must then compete with state law. Given the possibility of mandatory federal takeover regulation (and all its corresponding problems), we cast our lot with the present state system of corporate law competition.

\section{CONCLUSION}

In many markets, competition is not only accepted but embraced. Rather than rely on a central planner to identify people's tastes and preferences and take into account the inpact of decisions on external parties in allocating goods and services, we use the market. And for good reason. At best regulators may lack expertise and therefore make errors. At worst, regulators may suffer from industry capture or may pursue their own personal objectives. Simply because the market in question is the market for corporate law rules does not alter the problems facing centralized regulators. The real question in assessing any proposal targeting state competition in corporate law rules is whether competition, given all its flaws, results in a better set of rules for shareholders than centralized regulation, with all its flaws.

Bebchuk and Ferrell's proposal seeks to increase shareholder welfare. Significantly, the proposal works through increased competition. But once one accepts that choice among regulatory regimes improves shareholder welfare, several criticisms of Bebchuk and Ferrell's proposal emerge. Their proposal of a federal regulatory regime provides less choice than would other possible alternatives. Indeed, a federal takeover regine is but one

\footnotetext{
* Bebchuk \& Ferrell, supra note 9, at 160. Bebchuk and Ferrell simply put this forward as a possibility and stop short of suggesting that it is in fact an accurate description of shareholder choice.
} 
possible choice along a continuum of choices. They fail to take choice to its logical conclusion to include a wide range of other corporate law options, including private suppliers of corporate law rules.

Bebchuk and Ferrell's shareholder opt-in proposal leans heavily on their faith in shareholder voting. Here we remain agnostic. On the one hand, many reasons exist to worry about shareholder voting. Large block shareholders may threaten to initiate a shareholder vote to extort inoney from the company. Small shareholders may face collective action and rational apathy problems in investigatimg the value of any particular vote. And the lack of adoption of unilateral shareholder voting regimes by companies going public today makes us pessimistic about the value of such a regime. Nevertheless, where shareholder voting works, it does hold some promise of protecting shareholders. Who better to protect the interests of shareholders than the shareholders themselves? If this is the case, however, why are Bebchuk and Ferrell so tentative? If shareholder voting works well, why not extend shareholder voting through the federal proxy rules to allow binding corporate governance issue proposals? Indeed, shareholders could be given more direct control over executive conpensation and other areas of the direct operations of a corporation.

Certainly Bebchuk and Ferrell's proposals may provide soine incremental benefit to the present state competition regime. As Bebchuk and Ferrell themselves state, providing a federal regime may or may not inake things better, but it probably will not make things worse. ${ }^{99}$ Likewise, the institution of unilateral shareholder voting as a default provision niay also improve state competition. What is important about Bebchuk and Ferrell is their willingness to work within the state competition framework. Although flawed, state competition in corporate law continues to provide better corporate law rules than would monopohstic federal regulation.

9 Id. at 149-50. 